\title{
Seasonally and experimentally induced changes in testicular function of the Australian bush rat (Rattus fuscipes)
}

\author{
D. C. Irby, J. B. Kerr, G. P. Risbridger and D. M. de Kretser
}

Department of Anatomy, Monash University, Clayton, Victoria 3168, Australia

\begin{abstract}
Summary. Serum concentrations of LH, FSH and testosterone were measured monthly throughout the year in male bush rats. Testicular size and ultrastructure, $\mathrm{LH} / \mathrm{hCG}$, FSH and oestradiol receptors and the response of the pituitary to LHRH were also recorded.

LH and FSH rose in parallel with an increase in testicular size after the winter solstice with peak gonadotrophin levels in the spring (September). The subsequent fall in LH and FSH levels was associated with a rise in serum testosterone which reached peak levels during summer (December and January). In February serum testosterone levels and testicular size declined in parallel, while the pituitary response to an LHRH injection was maximal during late summer. The number of $\mathrm{LH} / \mathrm{hCG}, \mathrm{FSH}$ and oestradiol receptors per testis were all greatly reduced in the regressed testes when compared to active testes.

In a controlled environment of decreased lighting (shortened photoperiod), temperature and food quality, the testes of sexually active adult males regressed at any time of the year, the resultant testicular morphology and endocrine status being identical to that of wild rats in the non-breeding season. Full testicular regression was achieved only when the photoperiod, temperature and food quality were changed: experiments in which only one or two of these factors were altered failed to produce complete sexual regression.
\end{abstract}

\section{Introduction}

Previous studies of wild populations of the Australian bush rat, Rattus fuscipes, have shown that the males of this species have a seasonal reproductive cycle (Warneke, 1971; Taylor \& Horner, 1973). During the summer breeding season they exhibit complete spermatogenesis, while in the winter months the spermatogenic cycle is arrested at the primary spermatocyte step. Serum LH, FSH and testosterone levels are significantly lower during the winter than during the breeding season (Kerr, Keogh, Hudson, Whipp \& de Kretser, 1980). The secretory function of Sertoli cells undergoes alteration as reflected by the content of androgen-binding protein in the testis and epididymis which becomes significantly lowered during the non-breeding season (Hodgson, Irby, Kerr \& de Kretser, 1979). Kerr et al. (1980) reported that Leydig cells during the non-breeding season were reduced in size, and showed a loss of smooth endoplasmic reticulum and mitochondria.

To study more fully the factors that control the seasonal reproductive cycle in bush rats, animals were collected at monthly intervals throughout the year for morphological and endocrinological studies. In addition, adult fertile males were placed in a controlled environment room where lighting, temperature and food were experimentally manipulated in an attempt to induce testicular regression. 


\section{Materials and Methods}

\section{Animals}

Throughout 12 months, more than 500 males were live-trapped in the wet sclerophyll forests of the Otway Ranges of Victoria $\left(38^{\circ} \mathrm{S}\right)$ using folding aluminium traps (Elliot Scientific Pty Ltd, Upwey, Victoria) baited with rolled oats, peanut butter and honey. Males were returned to the laboratory where they were classified as adult or sub-adult according to their occipital-nasal length, body weight (Warneke, 1971) and by testicular size or histological examination of the testes (Kerr et al., 1980).

\section{Experiments}

Change of lighting. Adult fertile males $(\mathrm{N}=40)$ captured in the wild during the summer months were maintained in a room at $20^{\circ} \mathrm{C}$ with $14 \mathrm{~h}$ light $/ 10 \mathrm{~h}$ dark $(14 \mathrm{~L}: 10 \mathrm{D})$ for at least 3 months. At a time which was coincidently also the season when natural testicular regression occurs, the lighting for 20 of the males was changed to $6 \mathrm{~L}: 18 \mathrm{D}$ for a 2 -month period. All animals were fed rat chow $a d$ libitum throughout the experiment. At the end of the experiment, all the animals were killed, and body, testicular, ventral prostate and seminal vesicle weights were determined and serum LH and testosterone levels were measured in each individual.

Change of lighting and temperature. From a group of 74 adult fertile males trapped during the late summer months and maintained on rat chow ad libitum at $20^{\circ} \mathrm{C}$ and $14 \mathrm{~L}: 10 \mathrm{D}$ for 3 months, 39 animals were transferred at the beginning of winter to a controlled environment room with a $6 \mathrm{~L}: 18 \mathrm{D}$ photoperiod and $12^{\circ} \mathrm{C}$ temperature. Testicular size was determined at the end of 2 months in both groups by measuring the length of the testes.

Change of lighting, temperature and food quality. Thirty-five adult, fertile rats were maintained in the laboratory at $20^{\circ} \mathrm{C}$ and $14 \mathrm{~L}: 10 \mathrm{D}$ during the winter months of June, July and August with ad libitum rat chow. At Day 0, 30 animals were fed a $3 \cdot 2 \%$ protein diet (Kellog's Rice Bubbles, $500 \mathrm{~g}$; cod liver oil, $10 \mathrm{ml}$; glucose, $10 \mathrm{~g}$; and dicalcium phosphate, $5 \mathrm{~g}$ ) ad libitum. The temperature and lighting were decreased by $2^{\circ} \mathrm{C}$ and 2 -h steps every 10 days until a $12^{\circ} \mathrm{C}$ and $6 \mathrm{~L} / 18 \mathrm{D}$ environment was reached (Text-fig. 1). At 17, 34, 54 and 77 days, 5-7 animals were killed. A control group of 10 animals fed normal rat chow ( $20 \%$ protein) and maintained throughout the experiment at $20^{\circ} \mathrm{C}$ and 14L : 10D were killed at the same time as the 77-day experimental animals. Tissues were fixed by vascular perfusion for microscopy (see below). Body, testicular and accessory sex gland weights were measured and serum samples obtained for $\mathrm{LH}$ and testosterone determinations.

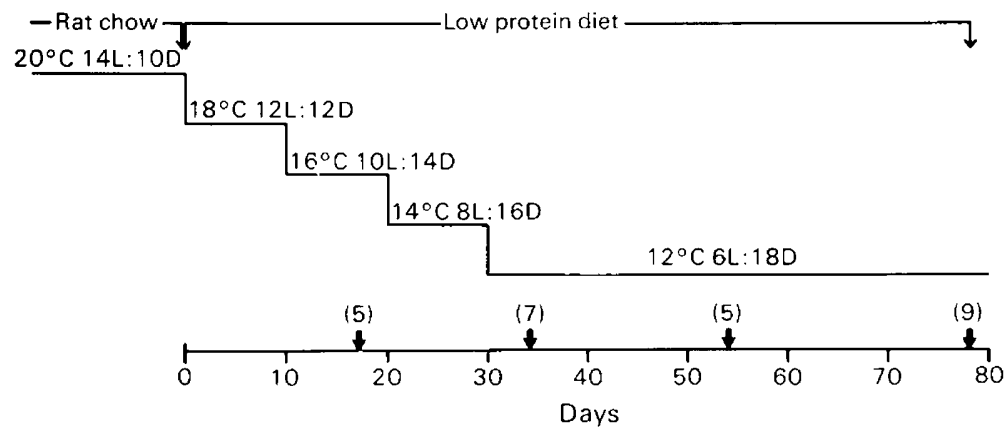

Text-fig. 1. Diagram indicating the changes of lighting, temperature and food quality. The times and numbers of animals killed are indicated by arrows. ${ }^{*}$ Controls maintained throughout the experiment on rat chow at $20^{\circ} \mathrm{C}$ and in $14 \mathrm{~L}: 10 \mathrm{D}$. 
Change of food quality. Five adult, fertile males were maintained at $20^{\circ} \mathrm{C}$ and $14 \mathrm{~L}: 10 \mathrm{D}$ on the low-protein diet for 10 weeks during the summer months of December, January and part of February. Testicular length and body weight were measured at the beginning and end of the study.

\section{Serum concentrations of $\mathrm{LH}, \mathrm{FSH}$ and testosterone}

Blood $(0.7 \mathrm{ml})$ was collected by cardiac puncture under light ether anaesthesia and serum was separated by centrifugation. LH and FSH were measured by specific double-antibody radioimmunoassays (RIA) which have previously been validated for the measurement of these hormones in the bush rat (Kerr et al., 1980). LH was expressed in terms of NIAMD-rat-LH-I1 and FSH concentrations were expressed in terms of NIAMD-rat-FSH-RP1 (Lee, de Kretser, Hudson \& Wang, 1975). Serial dilutions of sera and pituitary extracts from the bush rat were parallel to the standard curve. The minimum sensitivities were $0.08 \mathrm{ng} \mathrm{LH} / \mathrm{ml}$ and $70 \mathrm{ng} \mathrm{FSH} / \mathrm{ml}$. The intra- and inter-assay coefficients of variation for $\mathrm{LH}$ were $6.0 \%$ and $12 \%$, respectively and for FSH they were $4.0 \%$ and $7.0 \%$. Serum testosterone was measured with an RIA in which the antiserum was used against testosterone-3-carboxy-methoxime, coupled to porcine thyroglobulin. There was a $95 \%$ cross-reactivity with $5 \alpha$-dihydrotestosterone and the intra- and inter-assay coefficients of variation were $7.0 \%$ and $16.0 \%$ respectively. The minimum sensitivity was $0.02 \mathrm{ng} / \mathrm{ml}$.

\section{Serum $L H$ and FSH stimulation by $L H R H$}

Under light ether anaesthesia 5 rats were bled $(0.7 \mathrm{ml})$ from the jugular vein before and $45 \mathrm{~min}$ after a single injection of $250 \mathrm{ng}$ LHRH (Hoechst, Australia Ltd) per $200 \mathrm{~g}$ body weight. Serum was collected by centrifugation and LH and FSH concentrations were determined by RIA as described. The LHRH-stimulated levels of LH and FSH were expressed as the difference between the basal values and those after LHRH injection.

\section{In-vitro testicular gonadotrophin binding}

Saturation analyses were performed in vitro to assess the number of $\mathrm{LH} / \mathrm{hCG}$ and FSH binding sites in testicular membrane preparations from males with active or regressed testes. Membranes were prepared and the $\mathrm{LH} / \mathrm{hCG}$ and $\mathrm{FSH}$ binding were determined as has been previously reported (Risbridger, Kerr \& de Kretser, 1981). The specific activity was $40 \mathrm{Ci} / \mu \mathrm{g}$ for ${ }^{125} \mathrm{I}$-labelled hCG and $50 \mu \mathrm{Ci} / \mu \mathrm{g}$ for ${ }^{125} \mathrm{I}$-labelled FSH. The results were expressed as the amount of hormone bound per $100 \mathrm{mg}$ wet weight of tissue or as hormone bound per testis.

\section{In-vitro oestradiol binding to testicular cytosols}

The animals were killed by decapitation and the testes immediately excised and trimmed free of connective tissue and fat. After recording the weight, the testes were decapsulated and placed into ice-cold buffer. All subsequent procedures were carried out at $4^{\circ} \mathrm{C}$. The tissues were hand homogenized to a concentration of $1 \mathrm{~g} / 4 \mathrm{ml} \mathrm{TEM}$ buffer $(0.01 \mathrm{M}$-Tris, $1.5 \mathrm{~mm}$-EDTA and $5 \mathrm{mM}$ 2-mercaptoethanol), using a Teflon/glass homogenizer. The homogenates were centrifuged at $105000 \mathrm{~g}$ for $60 \mathrm{~min}$ to obtain a cytosolic supernatant that was assayed immediately or stored at $-20^{\circ} \mathrm{C}$ for no longer than 7 days. Protein concentrations of the cytosols were determined by the method of Bradford (1976). The specific binding of oestradiol to testicular cytosols was assessed in vitro using the charcoal adsorpition technique described by Abney (1976). Results were expressed as oestradiol bound per $\mathrm{mg}$ protein or as oestradiol bound per testis. 


\section{Morphology}

The testes from animals anaesthetized with ether were fixed by vascular perfusion through the thoracic aorta with a mixture of $2.5 \%$ glutaraldehyde, $2.0 \%$ formaldehyde and $0.05 \%$ trinitrocresol buffered to $\mathrm{pH} 7.4$ with $0.2 \mathrm{M}$-cacodylate. Post-fixation of $1 \mathrm{~mm}^{3}$ tissue blocks in $2.0 \%$ osmium tetroxide in $0.2 \mathrm{M}$-cacodylate buffer was followed by alcohol dehydration before the tissue was embedded in an Epon-araldite mixture. Sections $(1 \mu \mathrm{m})$ were stained with toluidine blue and examined by light microscopy. Thin sections for electron microscopy were examined using a Jeol $100 \mathrm{~S}$ electron microscope.

\section{Statistical analysis}

Data were analysed statistically by Student's $t$ test or analysis of variance with Duncan's multiple range test for comparison; $P<0.05$ (Student's $t$ test) and $P<0.01$ (Duncan's multiple range) were chosen as the levels of significance.

\section{Seasonal changes}

\section{Results}

Body weight, testicular length and daylength. Body weight did not change significantly in the adult males caught in the wild throughout the year (Text-fig. 2). The testicular length was significantly $(P<0.01)$ shorter in the winter months (June, July and August) than the summer

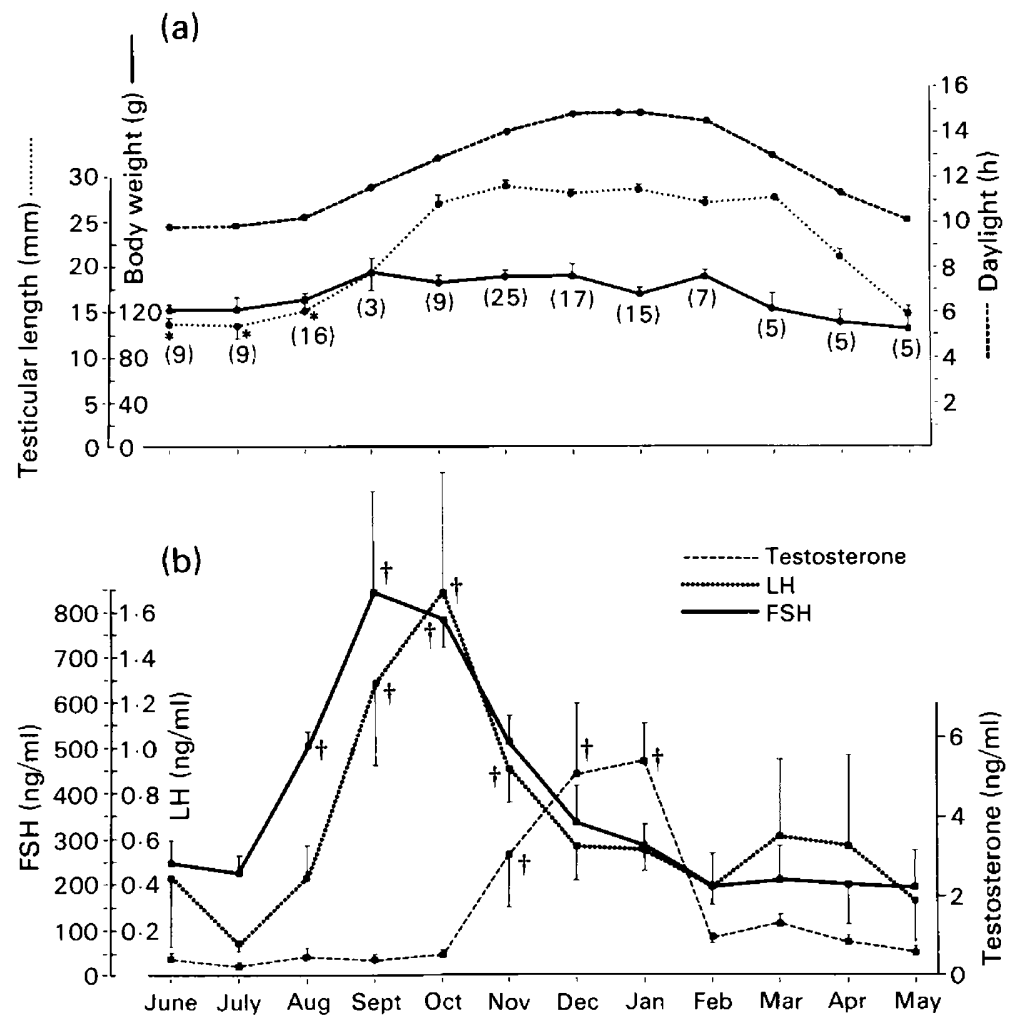

Text-fig. 2. Daylength and monthly estimations of (a) body weight and testicular length, and (b) serum concentrations of testosterone, LH and FSH. Values are mean \pm s.e.m. for the no. of animals indicated. ${ }^{*} P<0.01$ compared with values in December, January and February. $\dagger P<0.01$ compared with values in other months. 
months (December, January and February). The testes increased in size after the winter solstice and decreased after the summer solstice (Text-fig. 2a).

Serum concentrations of $\mathrm{LH}, \mathrm{FSH}$ and testosterone. Serum $\mathrm{LH}$ and FSH values rose and fell in synchrony, attaining peak levels in September-October and reaching a nadir February to July. Serum testosterone also varied seasonally, exhibiting a rise in November, attaining a peak during December-January and declining during January to October (Text-fig. 2b). The peak in testosterone occurred 2-3 months after peak levels of LH were attained.

$L H R H$ stimulation of $L H$ and $F S H$ release. The data are reported as the difference in serum $\mathrm{LH}$ and FSH concentrations $45 \mathrm{~min}$ after a single i.v. injection of $250 \mathrm{ng} \mathrm{LHRH} / 200 / \mathrm{g}$ bodyweight from the basal level at the time of injection. The greatest effect on the secretory response of the pituitary LHRH in terms of both LH and FSH occurred between January and March with the smallest response occurring in rats captured during June-November (Text-fig. 3).

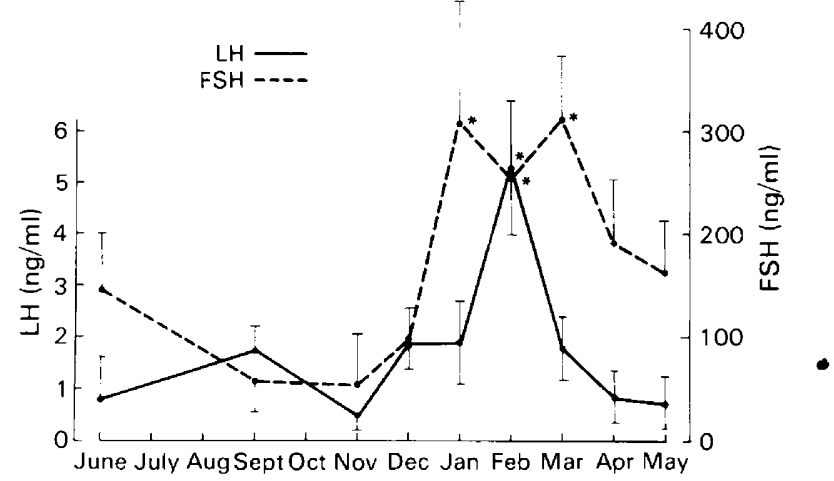

Text-fig. 3. Seasonal differences between the basal concentrations of serum LH and FSH and those after injection of LHRH. Values are mean \pm s.e.m. for 5 animals. ${ }^{*} P<0.01$ compared with values in other months.

Gonadotrophin binding to testicular membrane preparations. The $\mathrm{LH} / \mathrm{hCG}$ and FSH binding, when expressed as hormone bound per testis, showed a significant $(P<0.05)$ decrease in the regressed testes when compared to the testes with complete spermatogenesis (Table 1). However, if these data were expressed as hormone bound per $100 \mathrm{mg}$ wet weight tissue there was no apparent change. Since the change in testicular weight is due principally to a loss of germ cells and $\mathrm{LH} / \mathrm{hCH}$ and FSH binding are restricted to the Leydig and Sertoli cells respectively, the expression of the data per testis provides a more accurate estimation of the number of available receptors for gonadotrophins.

Table 1. Binding of ${ }^{125} \mathrm{I}$-labelled hCG/LH and FSH to testicular membrane preparations from bush rats with active or regressed testes

\begin{tabular}{|c|c|c|c|c|c|}
\hline \multirow{3}{*}{$\begin{array}{c}\text { Sexual } \\
\text { state }\end{array}$} & \multirow{3}{*}{$\begin{array}{c}\text { Testis } \\
w t \\
(\mathrm{~g})\end{array}$} & \multicolumn{4}{|c|}{ Gonadotrophin binding } \\
\hline & & \multicolumn{2}{|c|}{ 125 I-labelled hCG/LH } & \multicolumn{2}{|c|}{${ }^{125}$ I-labelled FSH } \\
\hline & & $\mathrm{pg} / 100 \mathrm{mg}$ testis & ng/testis & $\mathrm{pg} / 100 \mathrm{mg}$ testis & $\mathrm{ng} /$ testis \\
\hline Active & $7 \cdot 1 \pm 0 \cdot 4$ & $72 \cdot 9 \pm 10 \cdot 4$ & $29 \cdot 9 \pm 2 \cdot 1$ & $88 \cdot 2 \pm 2 \cdot 6$ & $5 \cdot 6 \pm 0 \cdot 1$ \\
\hline Regressed & $1 \cdot 5 \pm 0.3^{*}$ & $77 \cdot 4 \pm 8 \cdot 2$ & $4 \cdot 5 \pm 0.7^{*}$ & $86 \cdot 2 \pm 4 \cdot 1$ & $0.9 \pm 0.1^{*}$ \\
\hline
\end{tabular}

Values are mean \pm s.e.m. for 5 animals/group.

* $P<0.05$ compared with value for active testes (Student's $t$ test). 
Cytoplasmic oestradiol receptors. There was a significant $(P<0.05)$ decrease in cytoplasmic oestradiol receptors in preparations from regressed testes compared to those from fertile testes when the data were expressed as oestradiol per testis (Table 2).

Table 2. Oestradiol receptors in testicular cytosols from bush rats with active or regressed testes

\begin{tabular}{lccc}
\hline \multirow{2}{*}{$\begin{array}{c}\text { Sexual } \\
\text { state }\end{array}$} & \multicolumn{3}{c}{ Oestradiol binding } \\
\hline fmol/mg protein & fmol/testis & $K_{\mathrm{a}} \times 10^{10} \mathrm{M}^{-1}$ \\
\hline Active & $31 \cdot 6 \pm 1 \cdot 9$ & $1666 \cdot 7 \pm 88 \cdot 0$ & 1.8 \\
Regressed & $49.9 \pm 5 \cdot 1$ & $277.5 \pm 23 \cdot 1^{*}$ & 1.8 \\
\hline
\end{tabular}

Values are mean \pm s.e.m. for 5 animals/group.

${ }^{*} P<0.05$ compared with value for active testes (Student's $t$ test).

\section{Morphology}

Seminiferous tubules. The seminiferous tubules of animals trapped during the breeding season had the largest tubule diameter $(294.8 \pm 4.7 \mu \mathrm{m})$, with complete spermatogenesis in all tubules ( $\mathrm{Pl}$. 1, Fig. 1). As the testes regressed in March-May, the diameter of the tubules became smaller ( $83 \cdot 0$ $\pm 1.2 \mu \mathrm{m})$ due to a gradual decline in spermatogenesis, with the lumen of the tubule ultimately becoming obliterated by Sertoli cell cytoplasm. From June-August, spermatogenesis was arrested at the primary spermatocyte step, the tunica propria surrounding the seminiferous tubules was thickened and convoluted, and there was an accumulation of many lipid droplets within the seminiferous tubule (Pl. 1, Fig. 2). With the reinitiation of spermatogenic activity, during September-October, the number of lipid droplets decreased and the lumen was re-established within the tubule.

\section{PLATE 1}

Fig. 1. Light micrograph of the seminiferous epithelium during the summer breeding season in a wild caught bush rat, illustrating full spermatogenic activity. Spermatogonia (SG), primary spermatocytes (SC), round spermatids (rs), mature spermatids (ms) and Sertoli cell nuclei (S) are shown. $\times 1155$.

Fig. 2. Light micrograph of two seminiferous tubules illustrating cessation of spermatogenesis during the winter non-breeding season in a wild caught bush rat. The most advanced germ cell type is the primary spermatocyte (SC). Sertoli cell nuclei (S) and Sertoli cell lipid inclusions (L) are shown. Note the absence of a tubular lumen and thickened convolutions of the tunica propria (TP). Leydig cells often appear as aggregations of deeply staining cells (arrows). $\times 1155$.

\section{PLATE 2}

Fig. 3. Electron micrograph of Leydig cells from the bush rat testis during the non-breeding season, illustrating the remarkable number and morphology of Leydig cell crystalline inclusions (C) at times indenting (arrow) the Leydig cell nucleus (N). Aggregations of small crystalline inclusions $\left(^{*}\right)$ are commonly observed. Lipid inclusions (L) of various sizes are also illustrated. $\times 8075$.

\section{PLATE 3}

Fig. 4. Electron micrograph of a Leydig cell from an experimentally regressed testis, illustrating the presence of crystalline inclusions within the Leydig cell cytoplasm. Leydig cell nucleus $(\mathrm{N})$, mitochondria $(\mathrm{M})$ and smooth endoplasmic reticulum (arrow) are shown. $\times 14200$. Inset: High magnification of crystalline inclusion illustrating the arrangement of crystalline material into a lattice-like pattern. $\times 106250$. 
PLATE 1

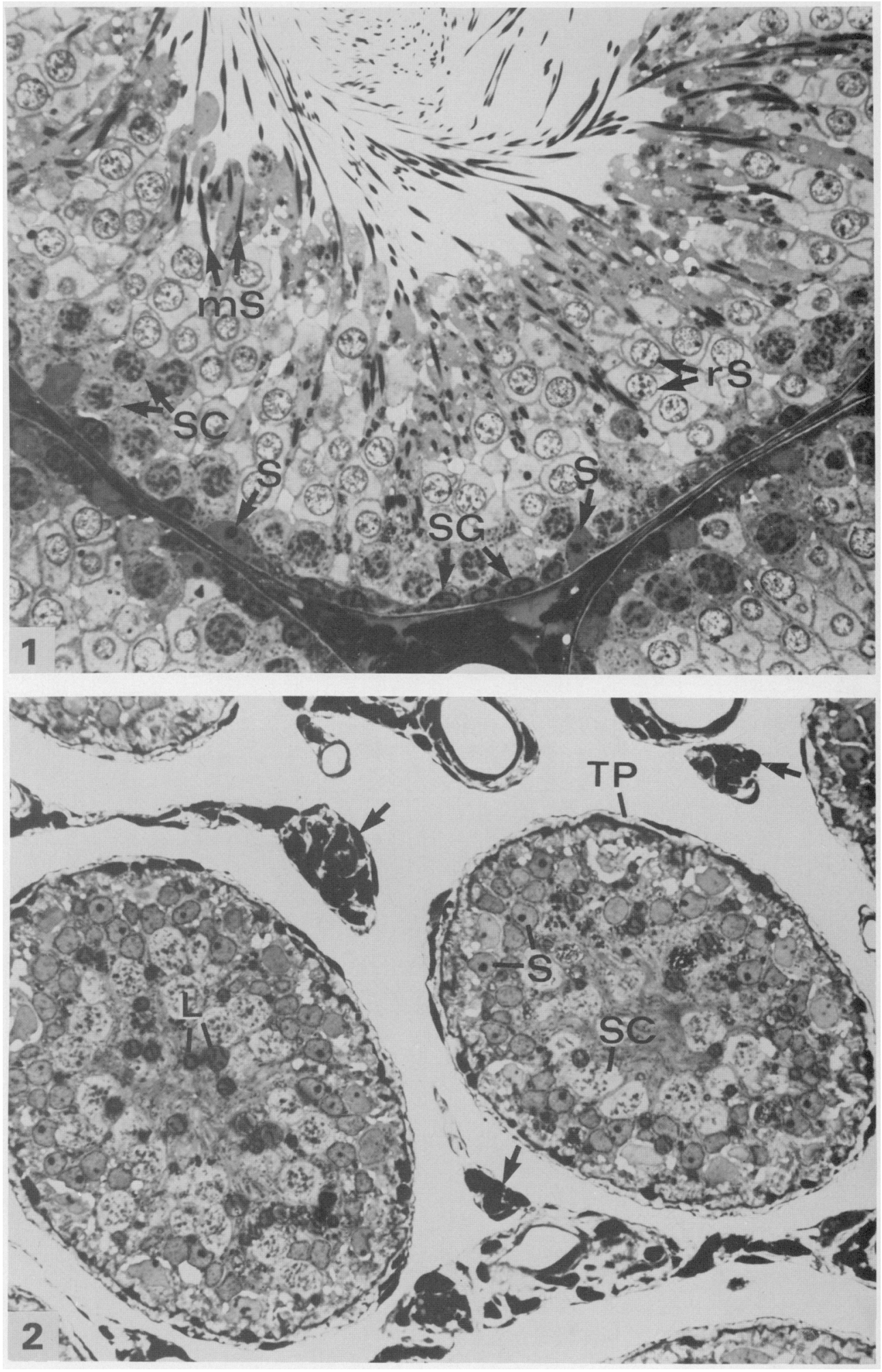

(Facing p. 662) 


\section{PLATE 2}

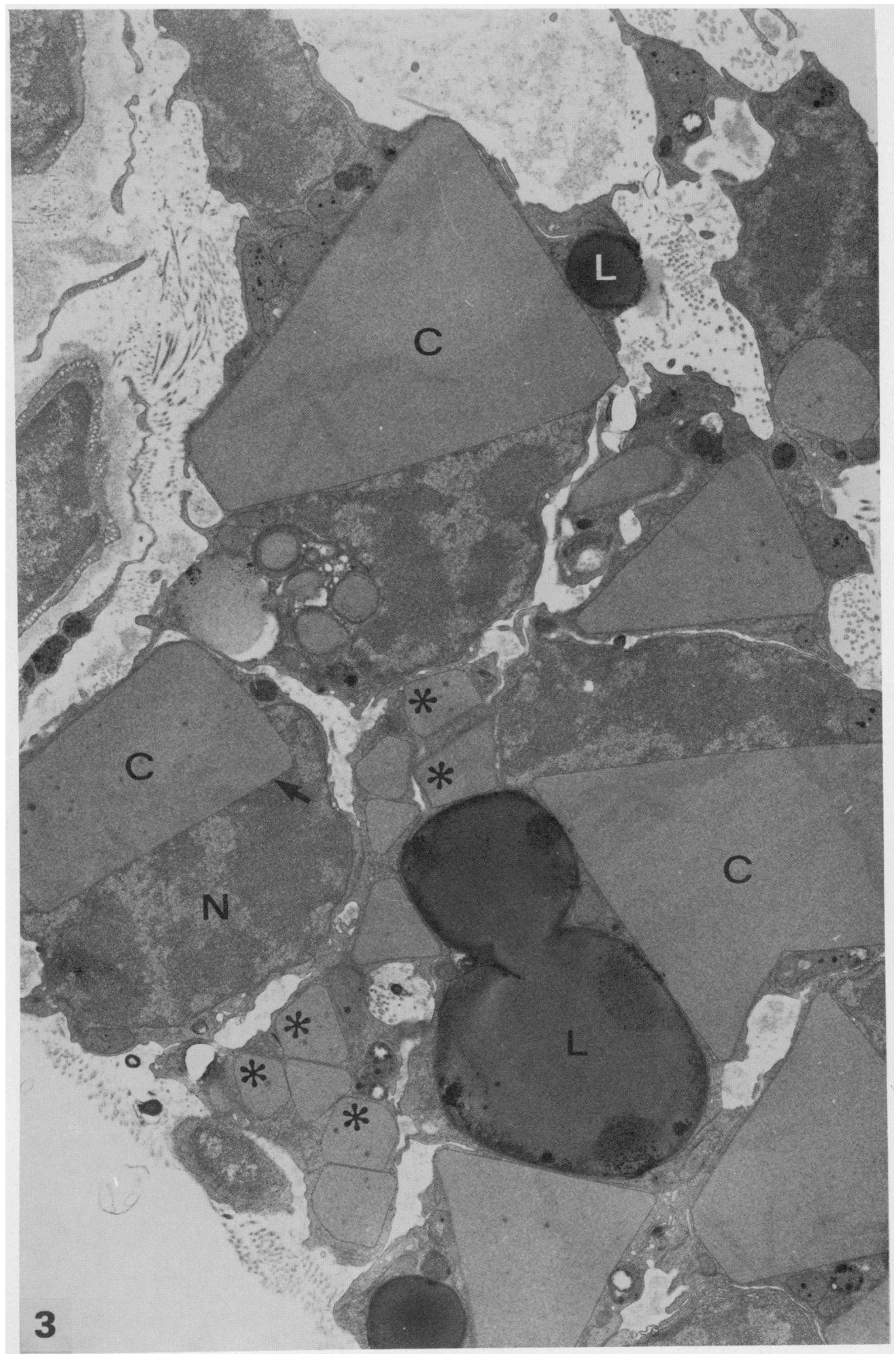


PLATE 3
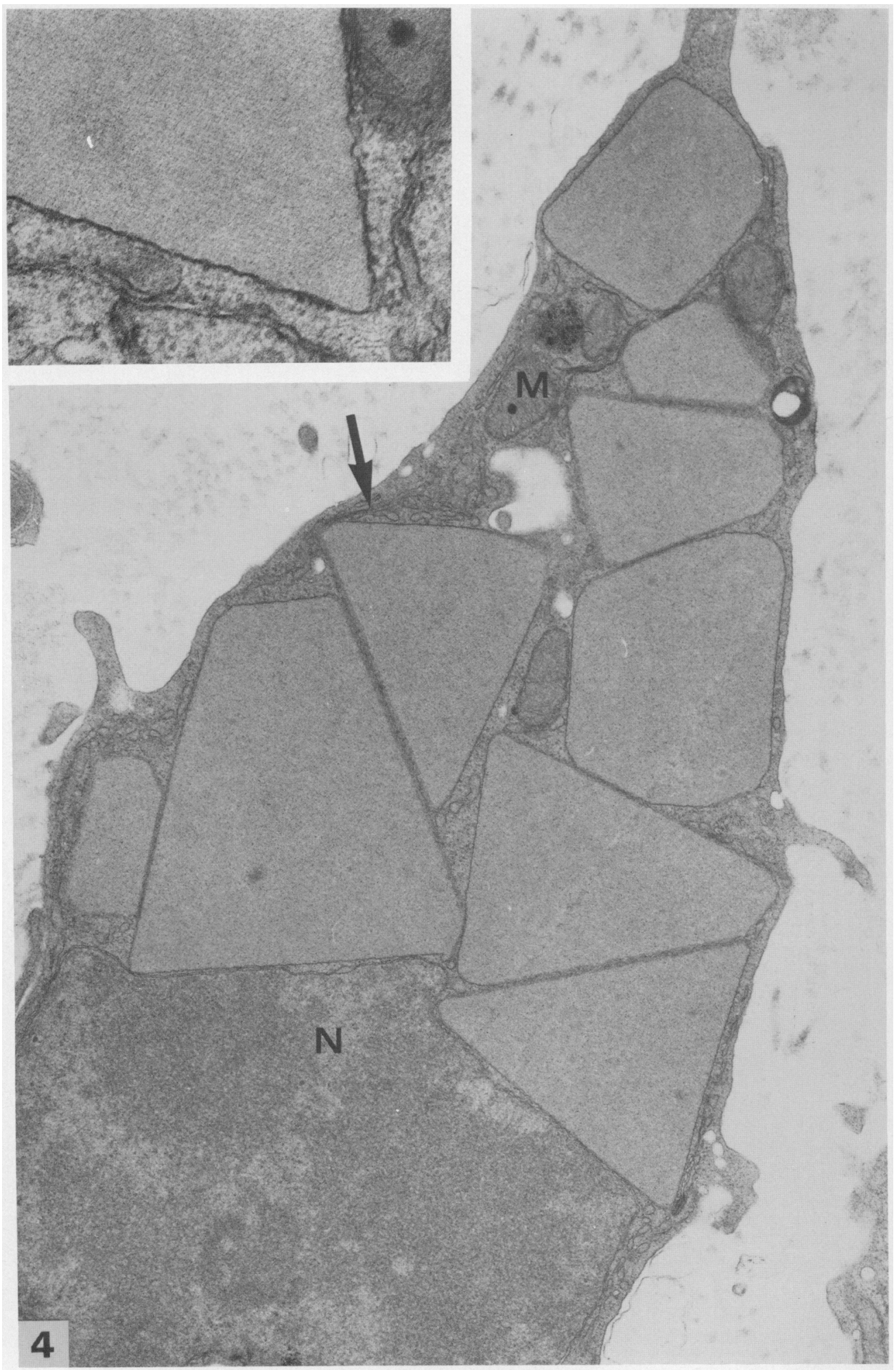

Downloaded from Bioscientifica.com at $\odot 4 / 26 / 2023$ 11:37:22AM 
Leydig cells. During the breeding season the Leydig cells were of maximum cross-sectional area $\left(96 \cdot 3 \pm 7 \cdot 1 \mu \mathrm{m}^{2}\right.$ (s.e.m.)) and contained abundant numbers of cytoplasmic organelles. As testicular regression proceeded during March-May, Leydig cells became reduced in cross-sectional area ( $52 \cdot 7$ $\pm 3.7 \mu \mathrm{m}^{2}$ ) and there was a concomitant decline in the content of the organelles within their cytoplasm. In particular, a reduction in the numbers of mitochondria and membranes of smooth endoplasmic reticulum was observed in association with declining spermatogenic activity. A progressive increase in the number and size of Reinke-like crystals was observed within the atrophied cell (Pl. 2, Fig. 3). During reinitiation of spermatogenesis there was an increase in Leydig ceil size, a disappearance of the cytoplasmic crystals and an increase in smooth endoplasmic reticulum and numbers of mitochondria.

\section{Experimental regression}

Change of lighting. The change in lighting from $14 \mathrm{~L}: 10 \mathrm{D}$ to $6 \mathrm{~L}: 18 \mathrm{D}$ for 2 months had no effect, compared to values for animals kept in $14 \mathrm{~L}: 10 \mathrm{D}$, on mean \pm s.e.m. body weight $(172 \pm 6$ and $194 \pm 18 \mathrm{~g}$, respectively), testicular weight $(6 \cdot 6 \pm 0.3$ and $7 \cdot 1 \pm 0.7 \mathrm{~g})$, ventral prostate weight $(405 \pm 25$ and $385 \pm 120 \mathrm{mg})$, seminal vesicle weight $(672 \pm 40$ and $728 \pm 48 \mathrm{mg}$ ), or concentrations of serum $\mathrm{LH}(1.75 \pm 0.5$ and $1.6 \pm 0.3 \mathrm{ng} / \mathrm{ml})$ and testosterone $(2 \cdot 8 \pm 0.7$ and $2.2 \pm$ $0.2 \mathrm{ng} / \mathrm{ml}$ ).

Change in lighting and temperature. When light and temperature were decreased to $6 \mathrm{~L}: 18 \mathrm{D}$ and $12^{\circ} \mathrm{C}$ for 2 months testicular length was significantly $(P<0.05)$ decreased from $27.8 \pm 0.8 \mathrm{~mm}$ in 36 control animals to $22.8 \pm 0.8 \mathrm{~mm}$ in 39 animals that were kept in decreased photoperiod and temperature. However, even though there was a significant decrease in testicular size, the testicular regression was not as great as the decrease from $28.6 \pm 0.3$ to $14.1 \pm 0.3 \mathrm{~mm}$ found in the wild population (Text-fig. 2a).

Changes in lighting, temperature and food quality. Because the protein content of food consumed by the wild rats is decreased during the time when the testes are regressing (Warneke, 1971), the rats were fed a low protein diet in combination with a decrease in photoperiod and temperature in an attempt to cause the same degree of testicular regression in the laboratory as that found in the natural environment. Due to a high mortality rate $(75 \%)$ when the temperature was decreased abruptly from 20 to $12^{\circ} \mathrm{C}$, the light and the temperature were gradually decreased in a step-wise manner when the diet was changed to a low protein content as shown in Text-fig. 1. After the first 34 days body weight and combined testicular weight were significantly $(P<0.01)$ decreased compared with controls (Text-fig. 4a). Prostate and seminal vesicle weights (Text-fig. $4 \mathrm{~b})$ and serum LH and testosterone (Text-fig. 4c) were significantly $(P<0.01)$ lower than those of controls after 17 days of treatment. Morphological examination of the testes showed a cessation of spermatogenesis after 54 days, with lipid accumulation in the Sertoli cells and the appearance of crystalloid inclusions within the atrophied Leydig cells. The morphology of the Leydig cells in experimentally regressed testes (P1. 3, Fig. 4) was identical to Leydig cells found in the naturally regressed testes (Pl. 2, Fig. 3). These results demonstrate that testicular regression in the laboratory, similar to that found in the wild, can be achieved with an appropriate combination of decreased temperature, photoperiod and protein content of the diet. The testicular regression in this experiment occurred during the spring when testicular redevelopment was taking place in the wild populations.

Changes in food quality. Since it has been reported that young laboratory rats maintained on a low protein diet have smaller testes than controls fed normal rat chow (Glass, Mellitt, Vigersky \& Swerdloff, 1979), it was possible that the decrease in testicular size in the rats maintained in conditions of decreased lighting, temperature and food quality was due entirely to the decrease in food quality with lighting and temperature having little or no effect. Therefore, 5 adult rats were kept for 10 weeks at $20^{\circ} \mathrm{C}, 14 \mathrm{~L}: 10 \mathrm{D}$ and fed the low-protein diet as previously described. Although there was a significant $(P<0.05)$ decrease in testicular length and weight $(25.4 \pm 0.9 \mathrm{~mm}$ and 6.2 


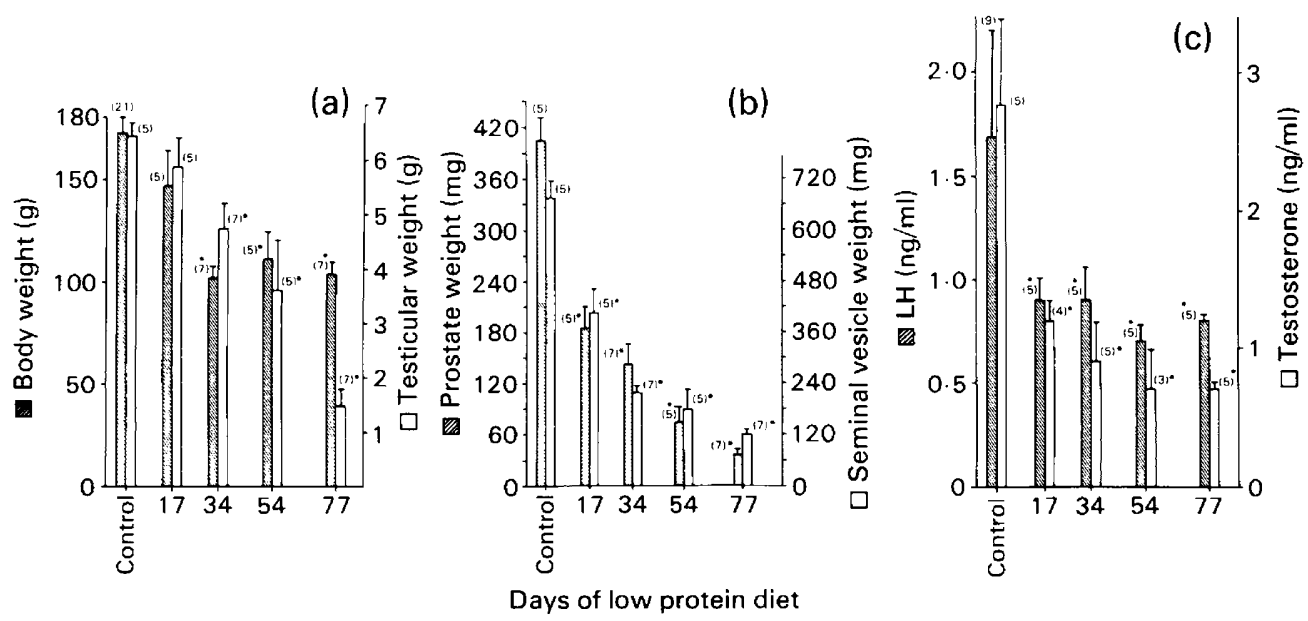

Text-fig. 4. Effect of decreasing the photoperiod, temperature and food quality on (a) body and testicular weight, (b) prostatic and seminal vesicle weights, and (c) serum $\mathrm{LH}$ and testosterone concentrations. Values are mean \pm s.e.m. for the no. of animals indicated. ${ }^{*} P<0.01$ compared to control values.

$\pm 0 \cdot 3 \mathrm{~g}$ in controls compared to $20 \cdot 2 \pm 1.7 \mathrm{~mm}$ and $5 \cdot 1 \pm 0.2 \mathrm{~g}$ in the test rats), the change was not as dramatic as seen after a change in lighting, temperature and food quality (Text-fig. 4a) or during natural regression (Text-fig. 2).

\section{Discussion}

The observations in this study on the wild-trapped rats confirm and extend previous studies that male bush rats are seasonal breeders (Warneke, 1971; Taylor \& Horner, 1973; Kerr et al., 1980). This study, however, expands and more clearly defines the changes of LH, FSH and testosterone concentrations in serum by frequent sampling from the wild population throughout a 12-month period. It is clear that there is a peak period for gonadotrophin and testosterone secretion and that they do not occur simultaneously. Serum testosterone values peak 2-3 months after the peak gonadotrophin concentrations even though gonadotrophin levels are decreasing. A similar observation has been reported for seasonally breeding Soay rams (Lincoln \& Peet, 1977) in which serum testosterone levels rose in parallel with an increase in testicular growth, as in this study, but were out of phase with LH levels which were declining at the same time. Lincoln \& Peet (1977) have suggested that the testes became more sensitive to the LH stimulation, resulting in enhanced testosterone secretion, and that, paradoxically, this increase in testosterone exerted a negative feedback on LH secretion by either modifying the pituitary response to LHRH or by suppressing the hypothalamic production of LHRH. Similarly, in this study the maximal increment in LH secretion due to exogenous LHRH stimulation occurred in February when the testosterone levels had declined. The subsequent decline in FSH and LH responsiveness to LHRH stimulation is probably the result of a lack of pituitary maintenance when there is a decreased endogenous LHRH secretion by the hypothalamus with the declining daylengths.

The reduction of $\mathrm{LH} / \mathrm{hCG}$ and FSH receptors and oestradiol cytosol binding in the regressed testes may represent a direct effect of decreased levels of circulating gonadotrophins, resulting in a decrease in membrane receptor maintenance. It is also possible that this loss in receptor number during the period of regression may be due to a decreased secretion of prolactin from the pituitary, as has been reported in another seasonal breeder, the golden hamster (Bex, Bartke, Goldman \& 
Dalterio, 1978). The actual role of oestrogen in the testes has yet to be elucidated, but there is evidence that a testicular oestrogen receptor is located in the interstitial tissue (Mulder, van Beurden-Lamers, Brinkman, Mechielsen \& Van der Molen, 1974). Whether the loss of oestrogen receptors during the period of testicular regression is a cause or effect has yet to be determined.

The morphological changes reported in this study have substantiated and expanded the work of Kerr et al. (1980), who examined tissue from males captured during the summer, autumn and winter but not during the re-initiation of breeding in the spring. Since samples were taken throughout the year in this study, it was clear that, as spermatogenesis was activated in the spring, there was a concomitant loss of lipid droplets from the Sertoli cells and a gradual disappearance of crystalloid inclusions from the cytoplasm of Leydig cells.

In this study of males with naturally and experimentally regressed testes, and as previously reported by Kerr et al. (1980), the appearance of these crystalloids during periods of testicular regression is associated with a hypogonadotrophinism and low serum levels. Conversely, this study shows a disappearance of the crystalloids concomitant with an increase in serum gonadotrophin levels. Clearly, the increase in size and numbers of the crystalloids found in the Leydig cells during the period of regression occurs when there is a loss of steroidogenic activity, but the physiological significance of these crystals is unknown.

In the present study, attempts were made to induce testicular regression by experimental manipulation. Unlike the results for hamsters (Hoffman, Hester \& Towns, 1965) and voles (Grocock, 1980), alteration of photoperiod alone did not result in testicular regression in bush rats. Combinations of shortening daylength and decreasing temperature induced partial regression as indicated by a declining testicular size but it required, in addition, a reduced protein intake to cause a complete regression. The fact that protein deprivation in the absence of changes in daylength and temperature also failed to induce a similar degree of testicular regression indicates that the effects on the testes are not those simply associated with the dietary change as has been described for laboratory rats (Glass et al., 1979). Because we were only interested in whether a protein content of the diet was sufficient to cause testicular regression, hormone levels were not measured. It is, however, quite clear from the size and weight of the testes that a decreased food quality alone is unlikely to be the sole cause of testicular regression in the wild population. It is very likely that nutritional factors are an important factor in the natural seasonal regression of testes seen in these animals since the bush rat has a summer diet consisting of mainly seeds and arthropods which supply a rich source of carbohydrates, fats and proteins. The protein content is decreased in the winter diet which primarily consists of fibrous plant tissue and fungi (Warneke, 1971). From the data presented here, it would seem that the changes in the state of the testes involve changes in daylength, diet and environmental temperature. The relative importance of these has yet to be determined. However, testicular regression of adult males can now be induced in the laboratory to a condition in which the testicular morphology and endocrinology are similar to those in males with naturally regressed testes. It is therefore possible to make direct comparisons between regressed testes and fertile testes in in-vitro and in-vivo experiments at any time of the year.

This study was supported by grants from the National and Medical Research Council of Australia and the Ford Foundation.

We thank Miss R. Peake, Mrs J. Clarke and Mr R. Allen for technical assistance; the many people who helped capture the animals, especially Dr J. Shelton; the Victorian Fisheries and Wildlife Division for trapping permits; and the Colac Water Trust for permission to trap animals in their water catchment areas.

\section{References}

Abney, T.O. (1976) A cytoplasmic estradiol-receptor in rat testicular tissue. Endocrinology $99,555-566$.
Bex, F., Bartke, A., Goldman, B.D. \& Dalterio, S. (1978) Prolactin, growth hormone, luteinizing hormone 
receptors, and seasonal changes in testicular activity in the golden hamster. Endocrinology 103, 2069-2080.

Bradford, M.M. (1976) A rapid and sensitive method for the quantitation of microgram quantities of protein utilizing the principle of protein-dye binding. Analyt. Biochem. 72, 248-254.

Glass, A.R., Mellitt, R., Vigersky, R.A. \& Swerdloff, R.S. (1979) Hypoandrogenism and abnormal regulation of gonadotropin secretion in rats fed a low protein diet. Endocrinology 104, 438-442.

Grocock, C.A. (1980) Effects of age on photo-induced testicular regression, recrudescence, and refractoriness in the short-tailed field vole Microtus agrestis. Biol. Reprod. 23, 15-20.

Hodgson, Y.M., Irby, D.C., Kerr, J.B. \& de Kretser, D.M. (1979) Studies of the structure and function of the Sertoli cell in a seasonally breeding rodent. Biol. Reprod. 21, 1091-1098.

Hoffman, R.A., Hester, R.J. \& Towns, C. (1965) Effect of light and temperature on the endocrine system of the golden hamsters (Mesocricetus auratus, Waterhouse). Comp. Biochem. Physiol. 15, 525-535.

Kerr, J.B., Keogh, E.J., Hudson, B., Whipp, G.T. \& de Kretser, D.M. (1980) Alterations in spermatogenic activity and hormonal status in a seasonally breeding rat Rattus fuscipes. Gen. comp. Endocr. 40, 78-88.
Lee, V.W.K., de Kretser, D.M., Hudson, B. \& Wang, C. (1975) Variations in serum FSH, L.H and testosterone levels in male rats from birth to sexual maturity. $J$. Reprod. Fert. 42, 121-126.

Lincoln, G.A. \& Peet, M.J. (1977) Photoperiod control of gonadotrophin secretion in the ram: a detailed study of the temporal changes in plasma levels of folliclestimulating hormone, luteinizing hormone and testosterone following an abrupt switch from long to short days. $J$. Endocr. 74, 355-367.

Mulder, R., van Beurden-Lamers, W.M.O., Brinkman, A.O., Mechielsen, M.J. \& Van der Molen, H.J. (1974) High affinity binding of oestradiol by rat testis interstitial tissue and by several other tissues of the male rat. J. Steroid Biochem. 5, 955-959.

Risbridger, G.P., Kerr, J.B. \& de Kretser, D.M. (1981) An evaluation of Leydig cell function and gonadotropin binding in unilateral and bilateral cryptorchidism: evidence for local control of Leydig cell function by seminiferous tubule. Biol. Reprod. 24, 534-540.

Taylor, M.J. \& Horner, B.E. (1973) Reproductive characteristics of wild native Australian Rattus (Rodentia: Muridae). Aust. J. Zool. 21, 437-475.

Warneke, B.M. (1971) Field study of the bush rat (Rattus fuscipes). Wildlife Contributions Victoria 14, 1-114.

Received 2 September 1983 